\title{
FAKTOR-FAKTOR YANG BERHUBUNGAN DENGAN PEMANFAATAN LAYANAN RAWAT JALAN
}

\author{
Factors Related to The Use of Outpatient
}

\section{Risnawati Valentina, Pujianto}

\author{
Health Policy and Administration Department Faculty of Public Health Universitas Indonesia, \\ F Building 1st Floor Kampus Baru UI Depok 16424, Indonesia \\ (risnawativalentina@gmail.com, 082221803665)
}

\begin{abstract}
ABSTRAK
Perkembangan jaminan kesehatan mulai berkembang dengan adanya Jaminan Kesehatan Nasional (JKN) sejak tahun 2014 yang dilaksanakan oleh Badan Penyelenggaraan Jaminan Sosial (BPJS) Kesehatan. Pemanfaatan layanan rawat jalan juga mengalami peningkatan baik rawat jalan maupun rawat inap. Oleh sebab itu, tujuan penelitian ini adalah melihat distribusi perilaku perokok, pelayanan rawat jalan, dan faktor- faktor yang berhubungan dengan pemanfaatan layanan rawat jalan di Indonesia. Penelitian ini menggunakan data Indonesia Family Life Survey 5 (IFLS 5) tahun 2014-2015 dengan desain penelitian cross-sectional dan pendekatan kuantitatif di mana pengukuran variabel independen dan variabel dependen yang dilakukan pada Maret 2019. Teori pemanfaatan layanan kesehatan oleh Andersen mencakup predisposing (umur dan jenis kelamin), enabling (ke pemilikan jaminan kesehatan), dan need (status perokok dan penyakit yang berhubungan dengan perilaku merokok). Hasil yang diperoleh adalah distribusi frekuensi pemanfaatan layanan rawat jalan selama empat minggu sebesar 1.600 (13,4\%), distribusi frekuensi perilaku merokok sebesar $10.396(86,9 \%)$, dan variabel umur, jenis kelamin, ke pemilikan jaminan kesehatan, status perokok dan penyakit yang berhubungan dengan perilaku merokok berhubungan signifikan dengan pemanfaatan layanan rawat jalan dengan $\mathrm{p}$ value $=0,00$. Pemanfaatan layanan rawat jalan dipengaruhi oleh faktor dalam dan luar diri.
\end{abstract}

Kata kunci : Pemanfaatan layanan, determinan, perokok

\section{ABSTRACT}

The development of health insurance began to develop with the existence of the National Health Insurance (JKN) since 2014 which was carried out by Badan Penyelenggaraan Jaminan Sosial (BPJS) Kesehatan. Utilization of outpatient services also experienced an increase in both outpatient and inpatient. Therefore, the purpose of this study is to look at the distribution of smokers' behavior, outpatient services, and factors related to the utilization of outpatient services in Indonesia. This study used Indonesian Family Life Survey 5 (IFLS 5) data for 2014-2015 with a cross-sectional research design and quantitative approach in which the measurement of independent variables and dependent variables was carried out in March 2019. Andersen's use of health services includes predisposing (age and gender), enabling (ownership the health insurance), and need (smoker status and diseases related to smoking behavior). The results obtained were the frequency distribution of the use of outpatient services for four weeks of 1,600 (13.4\%), the frequency distribution of smoking behavior by 10,396 (86.9\%), and the variables of age, sex, ownership of health insurance, smoker status and diseases related to smoking behavior are significantly associated with utilization of outpatient services with $p$ value $=0.00$. The use of outpatient services is influenced by internal and external factors.

Keywords : Service utilization, determinant, smoker 


\section{PENDAHULUAN}

Pada tahun 2005, semua Negara Anggota WHO berkomitmen menjalankan Universal Health Coverage (UHC). Hal ini diilustrasikan oleh kemajuan menuju Millennium Development Goals (MDGs) terkait kesehatan dan penurunan uang tunai sebagai pembayaran layanan kesehatan ${ }^{(1)}$. Awalnya di Indonesia, jaminan kesehatan yang berjalan hanya jaminan kesehatan komersil/swasta. Namun, tahun 2014, BPJS Kesehatan mengambil peran besar dalam mengelola Jaminan Kesehatan Nasional (JKN) bagi seluruh masyarakat Indonesia dengan total peserta telah mencapai 218.132.478 di tahun 2019(2). Adanya perkembangan pada fasilitas kesehatan yang bekerjasama yaitu, Fasilitas Kesehatan Tingkat Pertama (FKTP) dan Fasilitas Kesehatan Tingkat Lanjutan (FKTL). Pada tahun 2018, FKTP yang telah bekerja sama dengan BPJS Kesehatan terdiri atas 9.842 Puskesmas, 4.883 Dokter Praktik Keluarga, 4.603 Klinik Pratama, 1.188 Dokter Gigi, 669 Klinik TNI, 562 Klinik Polri, dan 16 RS D Pratama. Sementara itu, di tingkat rujukan, dari sekitar 2.733 rumah sakit yang teregistrasi di seluruh Indonesia, sebanyak 2.268 RS telah menjadi mitra BPJS Kesehatan dan siap memberikan pelayanan kepada peserta JKNKIS $^{(3)}$. Pada tahun 2016, pemanfaatan rawat jalan di FKTP mencapai 120,9 juta, di poliklinik rumah sakit mencapai 49,3 juta, dan rawat inap di rumah sakit mencapai 7,6 juta. Sebesar $68 \%$ kasus di pelayanan RJTL adalah kontrol ulang fisioterapi dan pasien penyakit kronis. Pada tahun 2017, total pemanfaatan pelayanan kesehatan dari tahun 2014 telah mencapai 640,2 juta pemanfaatan atau jika dirata-ratakan sebanyak 612.055 pemanfataan per hari kerja ${ }^{(4)}$. Bahkan selama dua tahun terakhir, BPJS Kesehatan mengalami defisit akibat penyakit kronis yang tinggi mencapai Rp. 16,5 T paling besar disumbangkan oleh Penyakit Tidak Menular (PTM) $)^{(5)}$.

Prevalensi PTM mengalami peningkatan yaitu, kanker, stroke, penyakit ginjal kronis, diabetes melitus, dan hipertensi ${ }^{(6)}$. Biaya akibat PTM (penyakit jantung, kanker, dan penyakit paru obstruktif kronik) sebesar Rp. 3,4 T untuk rawat jalan dan Rp. 12,6 T untuk rawat inap di awal tahun 2014. Adapun dari penyakit tersebut sebesar $8 \%$ dari total kasus rawat jalan dan $28 \%$ kasus rawat inap ${ }^{(7)}$. Merokok merupakan salah satu faktor pendukung yang dapat meningkatkan pemanfaatan pelayanan kesehatan karena merupakan faktor risiko PTM. Jenis kelamin pria, perokok, atau memiliki polis asuransi meningkatkan kemungkinan menjadi pasien rawat inap ${ }^{(8)}$. Seperti dalam teori Andersen bahwa pemanfaatan layanan kesehatan dipengaruhi oleh faktor predisposing (umur, jenis kelamin), enabling (ke pemilikan jaminan kesehatan), dan need (status merokok dan riwayat penyakit yang berhubungan denga merokok) $)^{(9)}$.

Oleh sebab itu, tujuan penelitian adalah 1) mendeskripsikan pemanfaatan layanan rawat jalan, 2) mendeskripsikan status perokok, 3) menganalisis faktor-faktor (predisposing, enabling, dan need) apa saja dalam pemanfaatan layanan rawat jalan. 


\section{METODE PENELITIAN}

Penelitian ini merupakan penelitian dengan desain penelitian cross-sectional dan pendekatan kuantitatif. Analisis data dilaksanakan oleh peneliti pada bulan Maret tahun 2019. Menggunakan data sekunder Indonesia Family Life Survey 5 tahun 20142015 kerjasama RAND Corp, Santa Monic (USA) dengan Pusat Penelitian Kependudukan dan Kebijakan (PPKK) Universitas Gadjah Mada. Populasi IFLS5 adalah 34.265. Sedangkan, sampel dengan kriteria inklusi individu yang memiliki perilaku merokok 11.962. Peneliti mengumpulkan data dengan mengakses www.rand.org mendaftarkan account kemudian mendownload data yang dibutuhkan. Analisis data dilakukan secara univariat dan bivariat dengan regresi logistic.

\section{HASIL}

Dari tabel 1 dapat mengetahui distribusi frekuensi pemanfaatan layanan rawat jalan selama empat minggu sebesar $1.600(13,4 \%)$, sedangkan frekuensi yang tidak memanfaatkan layanan rawat jalan selama empat minggu sebesar lebih besar yaitu, 10.362 (86,6\%).

Tabel 1. Distribusi Pemanfaatan Layanan Rawat Jalan (dalam empat minggu)

\begin{tabular}{ccc}
\hline $\begin{array}{c}\text { Pemanfaatan } \\
\text { Layanan }\end{array}$ & Frekuensi & Persentase \\
\hline Tidak & 10.362 & 86,6 \\
Ya & 1.600 & 13,4 \\
\hline Total & 11.962 & 100 \\
\hline
\end{tabular}

Sumber : Data IFLS5 yang diolah, 2019

Dari tabel 2 distribusi frekuensi perilaku merokok sebesar 10.396 (86,9\%), sedangkan frekuensi berhenti merokok $1.566(13,1 \%)$.

Tabel 2. Distribusi Perilaku Merokok

\begin{tabular}{ccc}
\hline & Frekuensi & Persentase \\
\hline Perokok & 10.396 & 86,9 \\
Berhenti & 1.566 & 13,1 \\
\hline Total & 11.962 & 100 \\
\hline
\end{tabular}

Sumber : Data IFLS5 yang diolah, 2019

Dari tabel 3, ke lima variabel signifikan dengan $\mathrm{p}$ value $=0,00$. Faktor predisposing (umur dan jenis kelamin), enabling (ke pemilikan jaminan kesehatan), dan need (status merokok dan penyakit yang berhubungan dengan perilaku merokok).

Tabel 3. Analisis Bivariat

\begin{tabular}{|c|c|c|c|c|c|c|c|c|}
\hline \multirow{3}{*}{ Independen Variabel } & \multicolumn{4}{|c|}{ Pemanfaatan Layanan Rawat Jalan } & \multirow{2}{*}{\multicolumn{2}{|c|}{ Total }} & \multirow{3}{*}{ OR } & \multirow{3}{*}{$P$ value } \\
\hline & \multicolumn{2}{|c|}{ Tidak } & \multicolumn{2}{|c|}{ Ya } & & & & \\
\hline & $\mathbf{n}$ & $\%$ & $\mathbf{n}$ & $\%$ & $\mathbf{n}$ & $\%$ & & \\
\hline \multicolumn{9}{|l|}{ Umur } \\
\hline Tidak produktif & 624 & 73,8 & 221 & 26,2 & 845 & 100 & \multirow[t]{2}{*}{0.004} & \multirow[t]{2}{*}{0.00} \\
\hline Produktif & 9.738 & 87,6 & 1.379 & 12,3 & 11.117 & 100 & & \\
\hline \multicolumn{9}{|l|}{ Jenis Kelamin } \\
\hline Laki-laki & 10.021 & 87 & 1495 & 13 & 11.516 & 100 & \multirow[t]{2}{*}{2.064} & \multirow[t]{2}{*}{0.00} \\
\hline Perempuan & 341 & 76,5 & 105 & 13,5 & 446 & 100 & & \\
\hline \multicolumn{9}{|l|}{ Ke pemilikan } \\
\hline Jaminan Kesehatan & & & & & & & \multirow{3}{*}{1.232} & \multirow{3}{*}{0.00} \\
\hline Tidak & 5.578 & 87,8 & 778 & 12,2 & 6.356 & 100 & & \\
\hline Punya & 4.784 & 85.3 & 822 & 14,7 & 5.606 & 100 & & \\
\hline \multicolumn{9}{|l|}{ Status merokok } \\
\hline Perokok & 9.185 & 88,4 & 1.211 & 11.6 & 10.396 & 100 & \multirow[t]{2}{*}{2.507} & \multirow[t]{2}{*}{0.00} \\
\hline Mantan Perokok & 1.177 & 75,2 & 389 & 24.8 & 1.566 & 100 & & \\
\hline \multicolumn{9}{|l|}{ Riwayat penyakit } \\
\hline Tidak & 9.045 & 89 & 1.119 & 11 & 10.164 & 100 & \multirow[t]{2}{*}{2.952} & \multirow[t]{2}{*}{0.00} \\
\hline Punya & 1.317 & 73,2 & 481 & 26.8 & 1.798 & 100 & & \\
\hline
\end{tabular}

Sumber : Data IFLS5 yang diolah, 2019 


\section{PEMBAHASAN}

\section{Faktor Predisposing}

Faktor predisposing terdiri dari faktor bawaan yang ada di dalamnya individu dan faktor sosial ekonomi lain yang kita asumsikan ada sebelum penyakit. Faktor tersebut dibagi menjadi dua bagian yaitu, tidak tetap (kepercayaan terhadap layanan kesehatan, pengetahuan mengenai informasi layanan kesehatan, pendidikan, pekerjaan) dan tetap (umur, jenis kelamin, ras, lamanya dalam suatu komunitas). Faktor predisposing yang akan dibahas adalah umur dan jenis kelamin. Ke duanya signifikan dalam penelitian ini. Hasil penelitian menyatakan bahwa jenis kelamin laki-laki $(\mathrm{P}=0,027)$, usia produktif $(\mathrm{P}=0,005)$, status belum menikah $(\mathrm{P}=0,001)$, dan orang yang tidak miskin $(P=0,034)$ cenderung menggunakan layanan kesehatan (10). Hasil penelitian lainnya menyatakan bahwa wanita memiliki tingkat pemanfaatan layanan kesehatan yang lebih tinggi dari pada pria di segala umur ${ }^{(11)}$.

\section{Faktor Enabling}

Suatu kondisi yang memungkinkan keluarga untuk bertindak berdasarkan suatu nilai atau memenuhi kebutuhan terkait utilisasi layanan kesehatan didefinisikan sebagai enabling Faktor enabling yang akan dibahas adalah ke pemilikan jaminan kesehatan (pemerintah/swasta). Hasil dari penelitian menyatakan bahwa adanya jaminan kesehatan dapat meningkatkan penggunaan layanan kesehatan, baik rawat jalan maupun rawat inap. Status jaminan kesehatan wajib (yang disponsori oleh pemerintah) sangat penting dalam pemanfaatan layanan dokter di antara kelompok berpenghasilan $\operatorname{rendah}^{(12)}$. Namun, dalam suatu penelitian menyatakan, kepemilikan asuransi komersil/swasta menentukan kemungkinan memilih rumah sakit swasta, tetapi tidak memiliki pengaruh dalam pemilihan penyedia layanan kesehatan masyarakat ${ }^{(13)}$.

\section{Faktor Need}

Definisi faktor need yaitu suatu persepsi (keadaan kesehatan, gejala penyakit, waktu yang tidak produktif karena sakit, suatu keadaan yang menyebabkan sakit) dan evaluasi (diagnosa kesehatan dari paramedis). Faktor need yang akan dibahas adalah status merokok dan penyakit yang berhubungan dengan rokok. Jika, adanya penyakit kronis yang terjadi menunjukkan sebagai salah satu penentu utama penggunaan perawatan kesehatan ${ }^{(14)}$. Perokok (laki-laki dan perempuan) akan cenderung memanfaatkan layanan perawatan kesehatan (dokter gigi dan dokter umum) dari pada yang tidak merokok ${ }^{(15)}$.

\section{KESIMPULAN DAN SARAN}

Faktor-faktor yang berhubungan signifikan dengan pemanfaatan layanan rawat jalan menurut Andersen adalah umur, jenis kelamin, ke pemilikan jaminan kesehatan, status merokok, dan penyakit yang berhubungan dengan perilaku merokok. Sarannya adalah mendorong masyarakat untuk lebih menjalankan upaya kesehatan preventif agar tidak meningkatnya pemanfaatan layanan rawat jalan. 


\section{DAFTAR PUSTAKA}

1. Maclennan M, Mason C, Mason E, Mbizvo M, Mendis S, Mertens T, et al. Research for Universal Health Coverage. Geneva; 2013.

2. BPJS Kesehatan. Peserta Program JKN [Internet]. 2019. Available from: https://bpjskesehatan.go.id/bpjs/home

3. Humas BPJS Kesehatan. Tahun 2018, BPJS Kesehatan Optimalkan Kerja Sama Fasilitas Kesehatan [Internet]. Jakarta; 2018. Available from: https://www.bpjskesehatan.go.id/bpjs/index.php/post/read/20 18/671/Tahun-2018-BPJS-KesehatanOptimalkan-Kerja-Sama-Fasilitas-Keseh

4. Humas BPJS Kesehatan. Sejarah Perjalanan Jaminan Sosial di Indonesia [Internet]. 2018. Available from: https://bpjskesehatan.go.id/bpjs/index.php/pages/detail/ 2013/4

5. Franedya Roy. BPJS Kesehatan Defisit Rp 16,5 T, Ini yang Dilakukan Direksi. 2018; Available from: https://www.cnbcindonesia.com/news/2018 0928112213-4-35182/bpjs-kesehatandefisit-rp-165-t-ini-yang-dilakukan-direksi

6. Kesehatan K. Riset Kesehatan Dasar 2018. Kementeri Kesehat. 2018;

7. Kesehatan K. Penyakit-penyakit katastropik tetap ditanggung program jkn. Kementeri Kesehat. 2017;1-2.

8. Samsudin S, Abdullah N. Healthcare Utilization by Older Age Groups in Northern States of Peninsular Malaysia: The Role of Predisposing, Enabling and Need Factors.
2017;223-37.

9. Andersen R, Newman J. Societal and Individual Determinants of Medical Care Utilization in the United States. 2005;83(4):1-28.

10. Gan-yadam A, Shinohara R, Sugisawa Y, Tanaka E, Watanabe T, Hirano M, et al. Factors Associated With Health Service Utilization in Ulaanbaatar, Mongolia: A Population-Based Survey. 2013;23(5):3208.

11. Moineddin R, Nie JX, Wang L, Tracy CS, Upshur REG. Measuring change in health status of older adults at the population level: The transition probability model. BMC Health Serv Res [Internet]. 2010;10(1):306. Available from: http://www.biomedcentral.com/14726963/10/306

12. Shin H, Song H, Kim J, Probst JC. Insurance, acculturation, and health service utilization among Korean-Americans. J Immigr Health. 2005;7(2):65-74.

13. Bakar AA, Samsudin S. Determinants of Health Care Seeking Behavior: Does Insurance Ownership Matters ? 2016;6:6-11.

14. Shao S, Wang M, Jin G, Zhao Y, Lu X, Du J. Analysis of health service utilization of migrants in Beijing using Anderson health service utilization model. 2018;1-12.

15. Keto J, Ventola H, Jokelainen J, Timonen M, Linden K, Ylisaukko-oja T, et al. Primary health care utilisation and its costs among middle-aged smokers. Eur J Heal Econ. 2017;18(3):351-60. 